\title{
Comprehensive performance measurement system, procedural fairness and managerial performance
}

\author{
Susiana Susiana \\ Faculty of Economics and Business Andalas University, Indonesia \\ Yusnaini Yusnaini \\ Faculty of Economics and Business, Sriwijaya University, Indonesia \\ Manatap Berliana Lumban Gaol \\ HKBP Nommensen University, Indonesia \\ Imam Ghozali \\ Fuad Fuad \\ Faculty of Economics and Business, Diponegoro University, Indonesia
}

Keywords
Ccomprehensive performance measurement system; procedural fairness; managerial performance.

\begin{abstract}
The aim of this study is to investigate the role of comprehensive performance measurement systems (CPMS) on managerial performance (MP), which is mediated by procedural fairnes. In order to generate the goal of the study, the researchers conduct a survey study at manufaturing firms. We test our 84 usable data from middle and functional managers of the firms using Sstructural Equation Modelling analysis, in particularly Warp PLS 4.0. The results indicate that CPMS has a significant effect on managerial performance (MP) both directly and indirectly through procedural fairness (PF). This study demonstrates the importance of procedural justice implementation in companies with respect to the application of CPMS.
\end{abstract}

Corresponding author: Yusnaini Yusnaini

Email addresses for corresponding author: yusnaini_msi@yahoo.com

First submission received: $18^{\text {th }}$ September 2017

Revised submission received: $9^{\text {th }}$ January 2018

Accepted: $29^{\text {th }}$ January 2018

\section{Introduction}

The performance measurement system used to evaluate managerial performance to increase the efficiency and effectiveness of the company, especially related to managerial functions (Melnyk, S. A., U. Bititci, K. Platts, J. Tobias, and B. Andersen. 2014). Some experts suggest the importance and benefits of performance measurement systems (PMS), among others: it can be used to determine the progress of a company (Olsen et al. 2007; Mayer et al. 2007; Yuliansyah et al. 2017), involving the justice system can affect the employee performance in a company (Lau and Moser 2008; Yuliansyah et al. 2016) is an integral part of the management control system in achieving strategic priorities within an enterprise (Merchant and Van der Stede 2012; Olsen et al. 2007). The opinions of these experts imply that the importance of a comprehensive measurement system (CPMS) can be used to assess company performance, especially managerial performance.

A key role of a comprehensive performance measurement system is expressed by Verbeteen and Boons (2009) who state that a comprehensive performance measurement system comprises a range of measurements covering various important parts of an organization, integrated with strategy, organizational values, cross-functional and value chains. Burney and Widener (2007) state that the characteristic of a comprehensive performance measurement system is it has a broad range of on or variation of a comprehensive performance measurement. The same opinion has been raised by several researchers (Chenhall 2005; Yuliansyah et al. 2017; Wouters 2009) who state that a comprehensive performance measurement system is designed to measure performance in all important areas of a company. Moreover, the integration of measurement with organizational strategies and objectives 
provides performance information on the progress of dimensions of performance (Chenhall 2005; Burney et al. 2009). The more comprehensive performance measurement system increasingly provides an understanding of the linkages between business operations and strategy (Choong 2014). The importance of developing a comprehensive performance measurement system is to maintain the strategic area of a system both financial and non-financial.

Some previous studies from Micheli and Manzoni (2010), Ittner et al. (2003), Verbeeten and Boons (2009), Hoque (2014), Chenhall and Langfield-Smith (2007), Atkinson et al. (1997), Hyvonen (2007) and Burney et al. (2009) have conducted research on the CPMS on organizational performance. In general, the findings of the study found that the CPMS provides ambiguous findings (Micheli and Manzoni 2010), can improve the company's ROA and ROE (Ittner et al. 2003) and improve organizational performance (Verbeeten and Boons 2009; Hoque 2014), may increase combined financial measures (Chenhall and Langfield-Smith 2007; Atkinson et al. 1997). But some researchers have not found a clear finding. Hyvonen (2007) and Burney et al. (2009) have identified that broader measurement emphasis can be made with multiple performance measurements and is associated with market satisfaction and performance.

Kruis and Wadiner (2014) state that there are still few researches that examine the effect of performance measurement systems on individual behavior/managers. In his study, Hall (2008) states that CPMS can not affect individual performance directly but it must be through intervening variables. Some researchers have used several variables as intervening variables such as: Lau and Moser (2008) have used procedural fairness, organizational commitment as mediation, trust and justice variables (Sholihin 2013, Susiana et al. 2017), psychological empowerment and role clarity (Hall, 2008), role ambiguity and relevant job information (Burney and Widener 2007). These studies have not found a strong relationship between the CPMS and MP so as to provide a gap for researchers to be able to investigate further. In general, it can be concluded that the effect of CPMS on managerial performance (MP) cannot directly influence but must use mediation variables.

Viewed from the perspective of psychology, the use of CPMS will affect justice in the assessment of employee performance because employees are assessed from various aspects. With justice in the performance appraisal system, it will be able to increase employee satisfaction (Lau and Moser 2008; Sholihin 2013; Sholihin and Pike 2009), increasee incentives to be received by employees (Burney et al. 2009) and increase and improve managerial performance (Susiana 2017 et al.). Fairness and/or fairness in a company's evaluation system become the determining factor of employee behavior, including commitment and performance while in the company (Cropanzana et al. 2007). This is because that procedural fairness is a variable associated with the implementation of policy on the company. Based on that perspective, the research indicates that procedural fairness can mediate the relationship of CPMS and MP.

The purpose of this research is to identify the research that has been done about the effect of CPMS on MP mediated with PF. The needs and desires of the company for the creation and management of procedural fairness can encourage companies to implement the CPMS and will improve managerial performance. The results of research that has been done by previous researchers indicate that the CPMS against MP cannot directly influence but must be through the mediation variables. The mediation variable is PF.

\section{Literature Reviews and Hypotheses}

\subsection{Goal Setting and Organizational Justice Theory}

This research was developed based on the theory of goal setting and the theory of justice. This theory is claimed to provide an explanation of how feedback can affect performance (Solihin, 2013) and can explain how accounting information affects individual behavior (de Waal 2010). In addition, feedback will affect performance (cognitive perspective) as well as through internal work motivation (motivation perspective). The theory of justice is also used to support the relationships that exist between the constructs in this study. Colquitt et al. (2001) state that equality and the adopted justice theory are to explain why the performance measurement system can bring the perception of subjectivity that may affect each activity. When people feel the evaluation of its performance is not based on a fair process (procedural 
fairness) it will lead to ambiguity or inconsistency, they will behave in accordance with the performance measurement system.

\subsection{Procedural Justice}

Procedural justice is a form of fairness when the procedure is done within the organization to achieve a certain outcome (Colquitt et al. 2001). All procedures within the company are conducted in accordance with the principles of justice that organization has made to achieve. Procedural justice places greater emphasis an overall evaluation of companies such as organizational commitment and trust from the owners (McFarlin and Sweeney 1992). Procedural justice can be done depending on the decision-making process, perceptions of procedural fairness involve psychological consequences in a decision-making within the enterprise. In terms of firms, procedural justice can affect job satisfaction, individual attitudes with other individuals in interacting with companies (Lau and Moser, 2008).

\subsection{Comprehensive Performance Measurement System}

The literature about comprehensive performance measurement system (CPMS) has several important characteristics such as Kruis and Widener (2014) which outlines that CPMS has following characteristics: integrated (Hoque 2014), containing the meaning of balance scorecard included causal connectivity with strategy (Kaplan and Norton 2001), and its dimension contain meaning or elements of strategy (Bisbe and Malagueño 2012). Integrating measurement systems with strategies and providing information about important parts of the value chain and focus on outcomes (Taylor and Taylor 2013). Furthermore, A comprehensive performance measurement system can describe performance as a whole (Hall, 2008; 2011). Combining financial and non-financial performance to assess factors related to balanced scorecard perspectives (Hoque, 2014).

\subsection{Managerial Performance}

Performance or achievement is work achieved by a person or a group of people within a company, in accordance with their respective powers and responsibilities in duties and responsibilities afforded to them in order to achieve company's objectives (Mahoney et al. 1965). Managerial performance focuses on how well a person is managing job responsibilities for carrying out planning, coordinating and controlling functions of responsibility center activities. Information about managerial performance can be used as a tool to motivate managers. However, economic performance focuses on how well a responsibility center works as an economic entity.

\subsection{Comprehensive Performance Measurement System and Managerial Performance}

A company can integrate performance measurement system by using information that would affect the result of managerial jobs (managerial's job outcomes) that is linked to the performance of managers. Thus, a performance measurement system will have an impact on a manager primarily related to the process and its objectives. Such information can assist managers in performing their duties and functions. This statement is supported by Chenhall and Langfield-Smith (2007) who state that companies use accounting information to evaluate manager performance.

Comprehensive performance measurements provide positive support for goal setting because: first, the purpose of which measured more influence in the evaluation of high performance and the use of a high standard (Sholihin et al. 2011). Second, performance measures provide feedback in the form of information (Burney et al., 2009). Feedback is required to improve the performance, people who have high levels of self-efficacy and when the purpose is challenging (Locke and Latham, 2013). Goal setting and feedback information on performance evaluation can influence decisions. This is aligned with individual goals and corporate goals (Sholihin, 2013). Therefore, we propose the following:

H1: Comprehensive performance measurement positively influences managerial performance.

\subsection{Comprehensive Performance Measurement and Procedural Fairness}

Comprehensive performance measurement is a performance measurement that will affect procedural fairness assessment in the application of company policy. Employee perceptions of procedural fairness carried out by superiors to evaluate performance are critical, assessing how they are treated and how the procedure is carried out. Justice in the work place is very important for employees. On a more personal level, justice meets some individual needs such as control need and the need for self-esteem and sense of 
belonging. In the context of performance measurement, employees tend to react positively to the fairness of their evaluation procedures and negatively to the injustice of the procedure. Procedural fairness in performance is likely to be a key evaluation of some important employee behaviors and provide a theoretical justification of how the performance evaluation influences employee and organizational commitment through result fairness and boss's trust.

Organizational fairness theory explains that performance evaluations are likely to be felt fairly when evaluation has access to detailed information about performance measures used and deems fairness highly relevant when performance evaluations are conducted uniformly and without prejudice among subordinates (Lau and Martin-Sardesai 2012). This allows employees to understand how their relationship with the company in the long run because the performance measurement system can comprehensively assess long-term performance. This assessment is carried out with the application of procedural fairness established by the company (Bellavance et al. 2013). If the company carries out a policy that is unfair, the decision can be remedied fairly (Colquit et al., 2001). Based on the above discussion, we suggest the following hypotheses:

\section{H2: Comprehensive performance measurement positively influences procedural fairness.}

\subsection{Procedural Fairness and Managerial Performance}

Implementation of procedural fairness in the company triggers the emergence of reactions to employees so that it can affect the managerial performance. If the implementation of procedure is good, it will be able to improve the performance of employees and managers and the vice versa; if the implementation of procedural policy is not run fairly, then it will trigger misunderstanding and will reduce employees' and manager's working enthusiasim.

Fair procedural in groups can simplify decision making by removing allocation bids to determine fair outcomes. It aims to avoid group conflict and tension, as well as establishing harmonious relationships within the group, and preventing group disunity. As a result, organizations that implement fair procedures tend to enjoy high levels of loyalty, commitment, and good performance from their employees. Lau and Mose (2008); Sholihin and Pike (2009) found a significant relationship between distributive justice and job satisfaction. In satisfaction with the performance evaluation process is expected to be associated with other forms of managers satisfaction, it makes sense to expect distributive justice (fair results) has positive relationship with performance.

Several studies have also found an association between procedural fairness and work performance (Lau and Moser, 2008; Lau and Sardesi, 2012). Sholihin (2013) found a high procedural fairness (sound and explanation combination) to be positively associated with performance improvement. Burney et al., (2009) and Bellavanca et al., (2013) state that the same perception of equity is found positively related to performance through goal commitment. Burney et al., (2009) found that procedural fairness is associated with accepted opinions or incentives. Therefore, we propose:

H3: The effect of procedural fairness is positively related to managerial performance

H4: There is indirect effect of procedural fariness, comprehensive performance measurement system and managerial performance.

\section{Research Method}

\subsection{Population and Sample}

This study uses a middle-level population of managers involved in finance. Managers categories are financial managers, human resources, marketing and operations in manufacturing companies listed in Indonesia Stock Exchange (BEI).

\subsection{Measure}

Comprehensive Performance Measurement System (CPMS) describes a comprehensive performance measurement system consisting of 9 items; 5 items represent the extent to which the CPMS provides performance information related to important parts of business operations. CPMS instrument was developed by Hall $(2008,2011)$ and be used by some authors such as (Yuliansyah and Khan 2015). The Procedural Fairness (PF) instrument is used to get a picture of certainty and perspective with the actual condition which is developed by Colquitt et al (2001). This instrument was used in Lau and Moser 
(2008); Sholihin et al., (2009) are research. The Managerial Performance (MP) is used to assess the performance of managers with nine performance dimensions that include managerial functions such as: planning, coordinating, evaluating, investigating, supervising staff, negotiating, representing, and monitoring overall performance (Mahoney et al., 1965). This instrument was used by some scholars such as Hall's (2008: 2011).

\subsection{Data Analysis}

To test the hypothesis, this research uses parallel structural equation model Partial Least Squares (PLS). PLS is used because it can give the coefficient of $p$ values for mediating variables and can be used for sample size relative and multi-colinearity between independent variables. The analysis of structural equation modeling with PLS does not require the data normally distributed (see: Yuliansyah et al. 2017; Yuliansyah and Khan 2017; Urbach and Ahlemann 2010). Hypothesis testing is done by estimating the measurement model and the structural model.

\section{Result}

\subsection{Data Analysis}

The result of data processing in Table 1 shows that loading composite reliability and cronbach alpha are above 0.70 (in Table 1). This proves that the instrument used to measure variables consistently result in the same results every time it is measured.

Table 1: Cronbach's alpha, Composite reliability coefisiien

\begin{tabular}{l|c|c|c}
\hline & Cronbach Alpha & Composite reliability & $\mathrm{R}^{2}$ \\
\hline CPMS & 0.883 & 0.902 & \\
\hline PF & 0.872 & 0.904 & 0.371 \\
\hline Managerial performance & 0.845 & 0.883 & 0.505 \\
\hline
\end{tabular}

Likewise, the variable value of loading each indicator is already above 0.70, indicating that the instruments constructed in this study have been able to collect data on the same pattern produced by other instruments to measure the same construct.

Table 2: Combined loading and cross loading

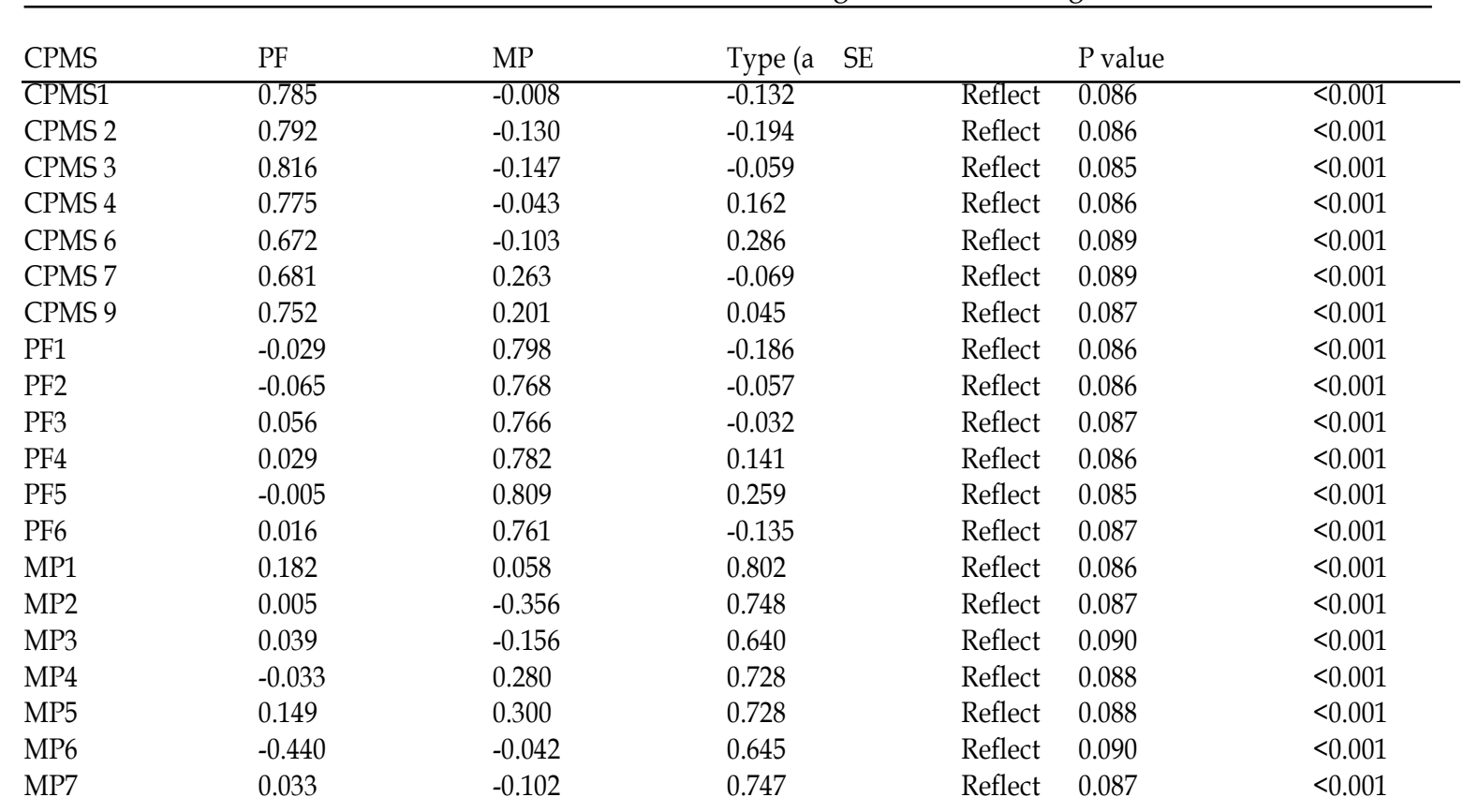

\subsection{Structural Model Analysis}

Structural model analysis is used to test the hypothesis. The first hypothesis is the existence of significant relationship of CPMS and MP based on the hypothetical test (see Table 3) with the application 
of CPMS with MP the coefficient is $0.289 ; \mathrm{p}<0.001$. In other words, the first hypothesis of this study can be accepted. Second hypothesis of CPMS with PF shows coefficient: 0,609; $p<0,001$. In other words, the second hypothesis of this study can be accepted, PF MP (coefficient: 0.470; $p<0.001$ ). In other words, the third hypothesis of this study can be accepted.

Table 3: Path coefficient and p-value

\begin{tabular}{|c|c|c|c|}
\hline & CPMS & PF & MP \\
\hline CPMS & & & \\
\hline $\mathrm{PF}$ & 0.609 & & \\
\hline MP & 0.289 & 0.470 & \\
\hline \multicolumn{4}{|c|}{ P values } \\
\hline & CPMS & PF & $\mathrm{MP}$ \\
\hline \multicolumn{4}{|l|}{ CPMS } \\
\hline $\mathrm{PF}$ & $<0.001$ & & \\
\hline MP & $<0.001$ & $<0.001$ & \\
\hline
\end{tabular}

Figure 1 shows the structural models, hypotheses H1 ( $\beta=0.289, p<0.01), \mathrm{H} 2(\beta=0.609, p<0.01), \mathrm{H} 1(\beta=$ $0.470, p<0.01)$, all of the relationships indicate positive and significant relationships.

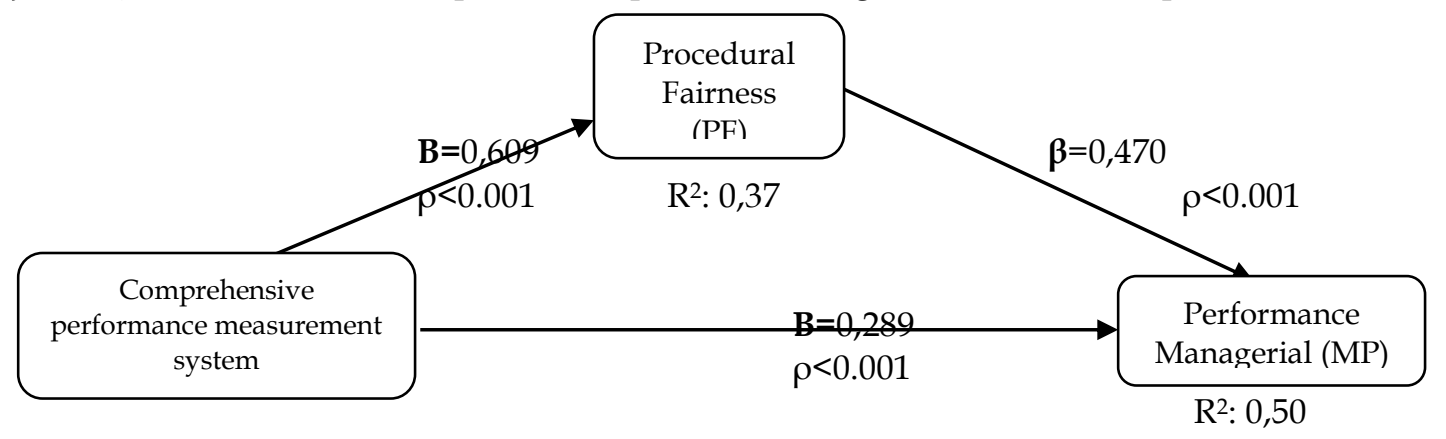

Figure 1: Result Research Model

\subsection{Result of Mediation}

Hypothesis $\mathrm{H} 4$ states that procedural fairness mediates the relationship between comprehensive performance measurement system and managerial performance. To build mediation, Baron and Kenny (1986) suggest three conditions must be met: "First, the independent variables should affect the dependent variable, second, independent variables should be shown to affect mediating variables, and third, the mediator should affect the dependent variable. The following illustrates the results of VAF calculation.

Based on the results of VAF calculations, PF mediates the relationship of comprehensive performance measurement system and managerial performance. It meets the requirements of mediation submitted by Baron and Kenny (1986), namely H1 CPMS $\rightarrow$ MP is significant at $0.289 \mathrm{p}<0.001$ (as per requirement 1, Relationship of CPMS $\rightarrow$ PF significant by 0,609 p<0.001 (as per requirement 2) Relationship PF $\rightarrow$ MP of $0.470 \mathrm{p}<0.001$ (as per requirement 3). It can be concluded that the effect of PF on CPMS and MP is $49.7 \%$ which means that procedural fairness meets as a partial mediator and suggests there are other factors influencing it. Thus, it shows the direct relationship and total influence of the relationship variable.

Table 4: Result Mediating Variable

\begin{tabular}{l|l}
\hline a) Indirect effect CPMS $\rightarrow \mathrm{PF} \rightarrow \mathrm{MP}$ & 0.286 \\
$0.609{ }^{*} 0.470$ & 0.289 \\
\hline $\mathrm{b})$. Direct effect CPMS and MP & 0.575 \\
\hline c). Total effect $=\mathrm{a}+\mathrm{b}$ & 0.497 \\
\hline d). VAF $=\mathrm{a} / \mathrm{c}$ & \\
\hline
\end{tabular}

\section{Conclusion}

This research investigates how the implementation of procedural fairness influences the system of comprehensive performance measurement and managerial performance at Indonesian manufacturing 
company. The results of empirical studies show that the implementation of procedural fairness has been executed in Indonesia. The results are consistent with Hartmann and Slapničar (2012) research which states that the implementation of procedural fairness affects the decision-making. These results also provide empirical evidence that the implementation of procedural fairness is high from the relationship of comprehensive performance measurement systems and managerial performance.

The result of the research shows that the CPMS significantly affects on the MP of 0.289 at $<0.001$, and the CPMS has significant effect on the PF of 0.609 at $<0.001$, PF has an effect on MP of 0.470 at $<0.001$. The indirect effect of this research is that PF mediates the relationship of CPMS and MP by 0.497. Thus, it can be concluded that in general the application of procedural fairness will be able to improve managerial performance.

The findings have practical implications by highlighting the importance of applying procedural fairness within a company. This can assist the company in understanding the importance of procedural fairness in the CPMS and the resulting influence, and ultimately can improve managerial performance and may be able to predict the likelihood of not running a fair procedure.

This research is expected to have theoretical implications and practical relevance. Theoretically this research will contribute to the literature on accounting management, in particular, the CPMS model, MP by integrating the goal setting theory and organizational justice theory. This research provides further insight into the behavioral implications and management accounting information. The results show that the CPMS can provide feedback and information needed by managers to do their job. The findings of this study are consistent with previous studies that indicate information from the CPMS and may have a positive effect on managerial behavior (Hall 2011; Yuliansyah and Khan 2015).

From a practical point of view, this research is expected to provide evidence in relation to the CPMS run by Indonesian manufacturing companies. This research gives implication to the implementation of CPMS to its behavior and practice to Indonesian company. The results of the study illustrate that procedural fairness can affect the use of CPMS and assist managers in designing policies and procedural implementation of PMS so as to reduce the ambiguity of roles at the managerial level.

Based on the results of research and discussion, it can be concluded that the implementation of procedural fairness has been successful and produced accounting information which is useful in decisionmaking. This study provides evidence that the implementation of procedural fairness becomes a high day for the company. This research also provides fundamental knowledge about the absorption of fairness especially procedural fairness in the company.

\section{Research limitations and direction for further research}

The limitation of this study is that the data collected using a questionnaire survey as a method of collecting data by sending a letter may not actually reach the intended respondent and affect the final result. Suggestions for future researchers are not only to consider the same topic but also to adopt a qualitative approach to gain further insights from the relationship of the variables studied. The use of a combination of methods by combining both quantitative and qualitative approaches may be able to provide more explanation of the research findings. Second, the sample used in this study is a single company i.e. the manufacturing sector, although randomly selected samples, the results may not be generalizable for other types of companies. Therefore, further research can also examine the companies of the service sector.

\section{References}

Atkinson, A. A., J. H. Waterhouse \& R. B. Wells (1997) 'A Stakeholder Approach to Strategic Performance Measurement' Sloan Management Review 38 (3), 25-37.

Baron, R. \& D. Kenny (1986) 'The moderator-mediator variable distinction in social psychological research: conceptual, strategic, and statistical considerations', Journal of personality and social psychology 51 (6), 1173-1182.

Bellavance, F., S. Landry \& E. Schiehll (2013) 'Procedural justice in managerial performance evaluation: Effects of subjectivity, relationship quality, and voice opportunity' The British accounting review 45 (3), 149-166.

Bisbe, J. \& R. Malagueño (2012) 'Using strategic performance measurement systems for strategy formulation: Does it work in dynamic environments?', Management Accounting Research 23 (4), 296-311.

Burney, L. \& S. K. Widener (2007) 'Strategic Performance Measurement Systems, Job-Relevant Information, and Managerial Behavioral Responses--Role Stress and Performance', Behavioral Research in Accounting 19, 43-69. 
Burney, L. L., C. A. Henle \& S. K. Widener (2009) 'A path model examining the relations among strategic performance measurement system characteristics, organizational justice, and extra- and in-role performance', Accounting, Organizations and Society 34 (3-4), 305-321.

Chenhall, R. H. (2005) 'Integrative strategic performance measurement systems, strategic alignment of manufacturing, learning and strategic outcomes: an exploratory study', Accounting, Organizations and Society 30 (5), $395-422$.

Chenhall, R. H. \& K. Langfield-Smith (2007) 'Multiple Perspectives of Performance Measures', European Management Journal 25 (4), 266-282.

Choong, K. K. (2014) 'Has this large number of performance measurement publications contributed to its better understanding? A systematic review for research and applications', International Journal of Production Research $52(14), 4174-4197$.

Colquitt, J. A., D. E. Conlon, M. J. Wesson, C. O. Porter \& K. Y. Ng. (2001) 'Justice at the millennium: a meta-analytic review of 25 years of organizational justice research: American Psychological Association'.

Cropanzana, R., D. E. Bowen \& S. W. Gilliland (2007) 'The management of organizational justice', The Academy of Management Perspectives, 34-48.

de Waal, A. (2010) 'Performance-driven behavior as the key to improved organizational performance', Measuring Business Excellence 14 (1), 79-95.

Hall, M. (2011) 'Do comprehensive performance measurement systems help or hinder managers' mental model development?', Management Accounting Research 22 (2), 68-83.

Hartmann, F. \& S. Slapničar (2012) 'The perceived fairness of performance evaluation: The role of uncertainty', Management Accounting Research 23 (1), 17-33.

Hoque, Z. (2014) '20 years of studies on the balanced scorecard: Trends, accomplishments, gaps and opportunities for future research', The British accounting review 46 (1), 33-59.

Hyvönen, J. (2007) 'Strategy, performance measurement techniques and information technology of the firm and their links to organizational performance', Management Accounting Research 18 (3), 343-366.

Ittner, C. D., D. F. Larcker, \& T. Randall (2003) 'Performance implications of strategic performance measurement in financial services firms', Accounting, Organizations \& Society 28 (7/8), 715.

Kaplan, R. S. \& D. P. Norton (2001) "'ransforming the Balanced Scorecard from Performance Measurement to Strategic Management: Part I', Accounting Horizons 15 (1), 87-104.

Kruis, A.-M., \& S. K. Widener (2014) 'Managerial Influence in Performance Measurement System Design: A Recipe for Failure?' Behavioral Research in Accounting 26 (2), 1-34.

Lau, C. M., \& A. V. Martin-Sardesai (2012) 'The role of organisational concern for workplace fairness in the choice of $\hat{A}$ a performance measurement system' The British accounting review 44 (3), 157-172.

Lau, C. M., \& A. Moser (2008) 'Behavioral Effects of Nonfinancial Performance Measures: The Role of Procedural Fairness' Behavioral Research in Accounting 20 (2), 55-71.

Locke, E. A., \& G. P. Latham (2013) New developments in goal setting and task performance, Routledge.

Mahoney, T. A., T. H. Jerdee \& S. J. Carroll (1965) 'The Job(s) of Management', Industrial Relations 4 (2), 97-110.

Mayer, D., L. Nishii, B. Schneider \& H. Goldstein (2007) 'The precursors and products of justice climates: Group leader antecedents and employee attitudinal consequences', Personnel Psychology 60 (4), 929-963.

McFarlin, D. B. \& P. D. Sweeney (1992) 'Distributive and Procedural Justice as Predictors of Satisfaction with Personal and Organizational Outcomes', The Academy of Management Journal 35 (3), 626-637.

Melnyk, S. A., U. Bititci, K. Platts, J. Tobias \& B. Andersen (2014) Is performance measurement and management fit for the future?', Management Accounting Research 25 (2), 173-186.

Merchant, K. A. \& W. A. Van der Stede (2012) Management control systems: performance measurement, evaluation and incentives, London, Prentice Hall.

Micheli, P. \& J.-F. Manzoni (2010) 'Strategic Performance Measurement: Benefits, Limitations and Paradoxes', Long Range Planning 43 (4), 465-476.

Olsen, E. O., H. Zhou, D. M. S. Lee, Y.-E. Ng, C. C. Chong \& P. Padunchwit (2007) 'Performance measurement system and relationship with performance results -A case analysis of a continous improvement approach to PMS design', International Journal of Productivity and Performance Management 56 (7), 559-582.

Sholihin, M. (2013) 'How Does Procedural Fairness Affect Performance Evaluation System Satisfaction? (Evidence from a UK Police Force)', Gadjah Mada International Journal of Business 15 (3).

Sholihin, M. \& R. Pike (2009) 'Fairness in performance evaluation and its behavioural consequences', Accounting $\mathcal{E}$ Business Research 39 (4), 397-413.

Susiana, S., Imam Ghozali, Fuad \& Zulaikha (2017) 'The Effect of The Comprehensive Performance Measurement System of Managerial Performance: Distributive and Interactional Justice as The Mediators', International Journal of Civil Engineering and Technology 8 (8), 334-342.

Taylor, A. \& M. Taylor (2013) 'Antecedents of effective performance measurement system implementation: an empirical study of UK manufacturing firms', International Journal of Production Research 51 (18), 5485-5498. 
Urbach, N. \& F. Ahlemann (2010) 'Structural equation modeling in information systems research using partial least squares', Journal of information Technology Theory and Application 11 (2), 5-39.

Verbeeten, F. H. M. \& A. N. A. M. Boons (2009) 'Strategic priorities, performance measures and performance: an empirical analysis in Dutch firms', European Management Journal 27 (2), 113-128.

Wouters, M. (2009) A developmental approach to performance measures - Results from a longitudinal case study, European Management Journal 27 (1), 64-78.

Yuliansyah, Y., B. Bui \& N. Mohamed (2016) How Managers Use PMS to Induce Behavioural Change in Enhancing Governance, International Journal of Economics and Management 10 (s2), 509-530.

Yuliansyah, Y., B. Gurd \& N. Mohamed (2017) 'The significant of business strategy in improving organizational performance', Humanomics 33 (1), 56-74.

Yuliansyah, Y. \& A. Khan (2017) 'A re-visit of the participative budgeting and employees' self-efficacy interrelationship -empirical evidence from Indonesia's public sector', International Review of Public Administration 22 (3).

Yuliansyah, Y. \& A. A. Khan (2015) 'Strategic Performance Measurement System: A Service Sector And Lower Level Employees Empirical Investigation', Corporate Ownership and Control 12 (3), 304-316. 